\title{
Arnoglossus nigrofilamentosus n. sp., a new species of flounder (Teleostei: Bothidae) from off the Mediterranean coast of Israel, probably a new case of Lessepsian migration
}

\author{
Ronald Fricke ${ }^{1}$, Daniel Golani ${ }^{2}$, Brenda Appelbaum-Golani ${ }^{3}$ \\ ${ }^{1}$ Im Ramstal 76, 97922 Lauda-Königshofen, Germany. \\ (RF) (Corresponding author) E-mail: ronfricke@web.de. ORCID iD: http://orcid.org/0000-0003-1476-6990 \\ ${ }^{2}$ National Natural History Collections and Department of Ecology, Evolution and Behavior, The Hebrew University of \\ Jerusalem, 91904 Jerusalem, Israel. \\ (DG) E-mail: dani.golani@mail.huji.ac.il. ORCID iD: http://orcid.org/0000-0003-4575-3324 \\ ${ }^{3}$ Mt. Scopus Library, The Hebrew University of Jerusalem, 91905 Jerusalem, Israel. \\ (BA-G) E-mail: brendag@ savion.huji.ac.il. ORCID iD: http://orcid.org/0000-0002-3237-6980
}

\begin{abstract}
Summary: The filamentous flounder Arnoglossus nigrofilamentosus n. sp. is described from four specimens collected in the southeastern Mediterranean near Tel-Aviv, Israel on 5 May 2017. The new species is characterized as follows: second to sixth dorsal-fin rays elongate and filamentous, dorsal-fin rays 78-84, anal-fin rays 61-66, pectoral-fin rays on ocular side 1213, on blind side 7-9, caudal-fin rays iii,11, iii, lateral-line scales 52-54, gill rakers $0+4-5$, not serrated, interorbital a narrow bony ridge without scales in the middle, interorbital width $11 \%$ to $16 \%$ of upper orbit diameter, no enlarged teeth anteriorly in upper jaw, and prevomer small, not enlarged, weakly projecting into mouth cavity; body in fresh specimens pale (may have been dark before the epidermis was abrased), head, peritoneum and vertical fins black. The new species is described and compared with similar species. Though the species has not yet been observed in the northern Red Sea, it probably originates from the Gulf of Suez, so this finding represents a probable new case of Lessepsian migration.
\end{abstract}

Keywords: Arnoglossus nigrofilamentosus; Bothidae; new species; distribution; Lessepsian migration; Red Sea.

Arnoglossus nigrofilamentosus n. sp., una nueva especie de platija (Teleostei: Bothidae) de las costas mediterráneas de Israel, probablemente un nuevo caso de migración lessepsiana

Resumen: Se describe una nueva especie de platija filamentosa Arnoglossus nigrofilamentosus n. sp. A partir de 4 ejemplares capturados en el SE Mediterráneo cerca de Tel-Aviv, Israel, el 5 de mayo del 2017. La nueva especie se caracteriza por los radios dorsales 2 a 6, largos y filamentosos, 78-84 radios dorsales, 61-66 radios anales, 12-13 radios pectorales en el lado ocular y 7-9 en el lado ciego, iii+11+iii radios caudales, linea lateral con 52-54 escamas, 0+4-5 arcos branquiales, no serrados, una estrecha cresta interorbital, sin escamas en medio, anchura interorbitaria 11-16\% el diámetro superior de la órbita, mandibular superior sin dientes alargados anteriormente, y prevomer pequeño, no alargado, débilmente proyectado en la cavidad bucal. En ejemplares frescos, el cuerpo es pálido (quizás oscuro antes de la abrasion de la piel durante la pesca), cabeza, peritoneo y aletas verticales negras. Se describe la nueva especie y se compara con especies próximas. Aunque la especie no se ha observado todavía en el Mar Rojo, probablemente es originaria del Golfo de Suez, lo que supondría un nuevo caso de migración lessepsiana.

Palabras clave: Arnoglossus nigrofilamentosus; Bothidae; nueva especie; distribución; migración lessepsiana; Mar Rojo.

Citation/Como citar este artículo: Fricke R, Golani D, Appelbaum-Golani B. 2017. Arnoglossus nigrofilamentosus n. sp., a new species of flounder (Teleostei: Bothidae) from off the Mediterranean coast of Israel, probably a new case of Lessepsian migration. Sci. Mar. 81(4): 457-465. doi: http://dx.doi.org/10.3989/scimar.04684.07A

LSID: urn:1sid:zoobank.org:pub:8A21CED5-D9EC-4AFF-95D6-C0AA6C6BA8A7

Editor: E. Macpherson.

Received: June 30, 2017. Accepted: October 10, 2017. Published: November 14, 2017.

Copyright: () 2017 CSIC. This is an open-access article distributed under the terms of the Creative Commons Attribution (CC-by) Spain 3.0 License. 


\section{INTRODUCTION}

The lefteye flounders of the family Bothidae are a large group of marine fishes living in tropical and temperate waters of all oceans. They are arranged in the order Pleuronectiformes (Nelson et al. 2016), and currently contain a total of 169 valid species (Eschmeyer and Fong 2017). The Bothinae (now classified as the family Bothidae) were characterized by Norman (1934) as left-eye flounders with the pelvic fin on the blind side short-based, that on the ocular side elongate, extending forward to urohyal, supported by a cartilaginous plate placed in advance of the cleithra, its anterior ray well in advance of first ray of that of the blind side, and caudal vertebrae with well-developed apophyses.

The genus Arnoglossus Bleeker, 1862 was defined by Amaoka (1969) by having the pelvic fin on the ocular side beginning at the tip of the isthmus, the eyes separated by a bony ridge or a very narrow concave space in the anterior half, interorbital equally wide in both sexes, head large, more than $22 \%$ of SL, the scales on the ocular side cycloid or feebly ctenoid, and the mouth large, maxillary longer than eye diameter. The genus is distributed in the eastern Atlantic and the Indo-Pacific; it currently includes a total of 34 valid species (Eschmeyer et al. 2017); a list of these species and their distribution is provided in Table 1.

While examining the catch of R/V Bilu collected off Jaffa, Israel in the morning of 5 May 2017, two of the authors (RF and DG) discovered four specimens of an unusual species of Arnoglossus, that was subsequently found to be an undescribed species. This species is described herein, and its probable origin is discussed.

\section{MATERIALS AND METHODS}

The specimens of the new species were trawled during the night of 4-5 May 2017 by R/V Bilu off Jaffa, Israel, eastern Mediterranean Sea, at a depth of approximately 20-40 m judging from the composition of other species contained in the same haul.

Counts and measurements follow Hubbs and Lagler (1947), and descriptive methods follow Arai and Amaoka (1996) except for the caudal-fin ray formula, which follows Fricke (1983); the classification follows Eschmeyer et al. (2017), and the references are according to Fricke (2017). In the description, data of the holotype are presented first, followed by those of the paratypes, in parentheses.

Comparative material. Arnoglossus arabicus: HUJ 13300 (9, 43.7$84.2 \mathrm{~mm} \mathrm{SL}$ ), Red Sea, Eritrea, $14^{\circ} 18^{\prime} \mathrm{N} 41^{\circ} 38^{\prime} \mathrm{E}$ (new record for the Red Sea); USNM 109488 (1), Yemen. Arnoglossus capensis: MNHN 1967-0506 (8), Liberia. Arnoglossus dalgleishi: MNHN 2014-2211 (2), New Caledonia, Chesterfield Islands; SMNS 23571 (1), Loyalty Islands, Lifou. Arnoglossus grohmanni (formerly known as A. kessleri): HUJ 13310 (7), Israel, Haifa; HUJ 17039 (1), Israel, Jaffa; HUJ 18627 (1), Israel, Zikim Beach; SMNS 11325 (4), Croatia, Cres Island; SMNS 11532 (1), Turkey, Muğla Province; SMNS 12416 (1), Baleares Islands, Formentera; SMNS 15734 (1), Greece, Chalkidiki; SMNS 16088 (1), Croatia, Cres Island; SMNS 16713 (1), Croatia, Cres Island; SMNS 19095 (1), Northern Cyprus, 9 km west Girne; SMNS 24486 (1), Croatia, Cres Island. Arnoglossus imperialis: HUJ 20600 (3), Balearic Islands, northwest of Menorca, 63-64 m depth; HUJ
20638 (1), Balearic Islands, northeast of Mallorca, 144-139 m depth. Arnoglossus laterna: HUJ 232 (1), Israel, Mediterranean coast; HUJ 6575 (3), Israel, Mediterranean coast; HUJ 6598 (2), Egypt, northern Sinai, Wadi Hesi; HUJ 6609 (1), Egypt, Bardawil, Katib el Galss; HUJ 7128 (4), Egypt, Bardawil; HUJ 8494 (1), Cyprus, Akrotiri; HUJ 8501 (2), Cyprus, Famagusta; HUJ 10947 (1), Israel, Tel-Aviv; HUJ 11333 (2), Israel, Ashdod; HUJ 12135 (6), Israel, Haifa; HUJ 13192 (6), Cyprus, Famagusta; HUJ 13205 (4), Israel, Mediterranean coast; HUJ 13246 (3), Israel, Rubin; HUJ 13247 (3), Israel, Rubin; HUJ 13295 (1), Cyprus, Famagusta; HUJ 13302 (4), Israel, Haifa; HUJ 13308 (1), Israel, Rubin; HUJ 13309 (1), Israel, Haifa; HUJ 13329 (2), Gaza Strip and Egypt, Gaza to Al Arish; HUJ 13332 (3), Israel, Rubin; HUJ 13333 (1), Israel, Kishon; HUJ 13676 (1), Cyprus, southeast of Paphos; HUJ 13677 (1), Cyprus, Famagusta; HUJ 13695 (1), Cyprus, southeast coast; HUJ 13827 (1), Israel, Jaffa; HUJ 13963 (3), Israel, Mediterranean coast; HUJ 13980 (1), Egypt, Bardawil, Katib el Galss; HUJ 13981 (2), Israel, Rubin; HUJ 13996 (1), Israel, Haifa; HUJ 17906 (2), Spain, Malaga; HUJ 20081 (2), Israel, Jaffa; SMNS 8761 (30), Italy, Santa Margherita Ligure; SMNS 9237 (1), Baleares Islands, Mallorca; SMNS 14981 (1), Turkey, Sea of Marmara; SMNS 20571 (4), Italy, Venice; SMNS 20571 (1), Italy, Venice. Arnoglossus macrolophus: HUJ 5147 (4), Eritrea; HUJ 13334 (7), Eritrea, Massawa; HUJ 20666 (4), Eritrea; MNHN 2014-1160 (3), Madagascar; MNHN 2014-1690 (3), Madagascar; MNHN 2014-2009 (1), Madagascar; MNHN 2014-2149 (4), Madagascar; SMNHTAU P.2062 (1), Israel, Eilat. Arnoglossus rueppellii: HUJ 13689 (1), Israel, Haifa; HUJ 13692 (1), Gaza Strip to Egypt, Gaza to El Arish; HUJ 13693 (1), Gaza Strip, Chan Yunis; HUJ 16099 (5), Israel, Hadera to Herzliya; HUJ 16508 (1), Israel, Ashdod; HUJ 16586 (3), Israel, Ashdod; HUJ 19066 (1), Israel, Haifa; SMNS 24438 (1), Madeira Region, Seine Seamount. Arnoglossus sayaensis: MNHN 2014-1625 (1), Madagascar; MNHN 2014-2189 (1), Madagascar; USNM 307494 (1), Saya de Malha Bank. Arnoglossus thori: HUJ 13202 (1), Israel, Mediterranean coast; HUJ 13240 (1), Cyprus, Famagusta; HUJ 13303 (1), Cyprus, Famagusta; HUJ 13322 (1), Cyprus, Famagusta; HUJ 13439 (2), Cyprus, Famagusta; HUJ 13678 (1), Israel, Tel-Aviv to Herzliya; HUJ 13709 (1), Israel, Haifa; HUJ 13938 (5), Israel, Hadera; HUJ 13986 (2), Israel, Haifa; HUJ 14058 (11), Israel, Caesarea; HUJ 18337 (1), Greece, Crete Island, Heraklion; HUJ 20601 (1), Balearic Islands, northwest of Mallorca, 63-64 m depth; HUJ 20610 (5), Balearic Islands, 111-109 m depth; HUJ 20612 (1), Balearic Islands, north of Mallorca, $65 \mathrm{~m}$ depth; HUJ 20622 (1), Balearic Islands, southsoutheast of Mallorca; HUJ 20665 (1), Israel, Jaffa; SMNS 9856 (4), Greece, Varkisa; SMNS 11587 (4), Greece, Varkisa; SMNS 15577 (1), Croatia, Cres Island; SMNS 16087 (1), Croatia, Cres Island. Arnoglossus sp.: SMNS 25264 (1), São Tomé and Principe.

\section{TAXONOMY}

\section{Arnoglossus nigrofilamentosus n. sp. Filamentous flounder} (Figs 1-2, Table 2)

Holotype: HUJ 20663, 1 male, $96.6 \mathrm{~mm}$ SL, Israel, vicinity of Jaffa, 20-40 m depth, trawl, R/V Bilu, 5 May 2017.

Paratypes: HUJ 20664, 3 males, 84.4-90.6 mm SL, same data as the holotype.

Diagnosis. A species of Arnoglossus with the second to sixth dorsal-fin rays elongate and filamentous, dorsal-fin rays 78-84, anal-fin rays 61-66, pectoral-fin rays on ocular side $12-13$, on blind side $7-9$, caudal-fin rays iii,11,iii, lateral-line scales 52-54, gill rakers $0+$ $4-5$, not serrated, interorbital a narrow bony ridge without scales in the middle, interorbital width $11 \%$ to $16 \%$ of upper orbit diameter, no enlarged teeth anteriorly in upper jaw, and prevomer small, not enlarged, weakly projecting into mouth cavity; body pale (may have been dark before the epidermis was abrased), head, peritoneum and vertical fins black. 
Table 1. - Valid species in the genus Arnoglossus Bleeker, 1862 and their distribution, arranged according to their mean depth distribution. EA, eastern Atlantic; EI, eastern Indian Ocean; EP, eastern Pacific; MS, Mediterranean Sea; RS, Red Sea; WA, western Atlantic; WI, western Indian Ocean; WP, western Pacific.

\begin{tabular}{|c|c|c|c|}
\hline Species & Depth range $(\mathrm{m})$ & Geographical distribution & Remarks \\
\hline A. coeruleosticta (Steindachner, 1898) & shallow & EP: Juan Fernandez and Desaventurados Islands & \\
\hline A. andrewsi Kurth, 1954 & $6-38$ & EI, WP: Bass Strait and Tasmania, Australia & \\
\hline $\begin{array}{l}\text { A. yamanakai Fukui, Yamada and } \\
\text { Ozawa, } 1988\end{array}$ & $20-30$ & WP: East China Sea & \\
\hline A. grohmanni (Bonaparte, 1837) & $1-50$ & MS: Mediterranean and Black Sea & $\begin{array}{l}\text { Junior synonym: A. kessleri } \\
\text { Schmidt, } 1915\end{array}$ \\
\hline A. fisoni Ogilby, 1898 & $26-50$ & WP: New South Wales and Queensland, Australia & \\
\hline $\begin{array}{l}\text { A. micrommatus Amaoka, Arai and } \\
\text { Gomon, } 1997\end{array}$ & $5-60$ & EI: southwestern Australia & \\
\hline A. bassensis Norman, 1926 & $10-70$ & $\begin{array}{l}\text { EI, WP: Southern Australia to New South Wales, } \\
\text { Australia }\end{array}$ & \\
\hline A. aspilos (Bleeker, 1851) & $30-71$ & $\begin{array}{l}\text { EI, WP: Persian Gulf east to Philippines and New } \\
\text { Guinea }\end{array}$ & \\
\hline A. waitei Norman, 1926 & $16-90$ & EI, WP: Arafura Sea and Queensland (Australia) & \\
\hline A. macrolophus Alcock, 1889 & $18-141$ & $\begin{array}{l}\text { RS, WI, EI: Central Red Sea, Persian Gulf and } \\
\text { Madagascar east to Indonesia }\end{array}$ & $\begin{array}{l}\text { Recorded from Eritrea, Red } \\
\text { Sea by Dor (1970) as } A \text {. } \\
\text { tapeinosoma (non Bleeker, } \\
1865 \text { ) }\end{array}$ \\
\hline A. tenuis Günther, 1880 & $80-100$ & EI, WP: northern Australia to southern Japan & \\
\hline A. muelleri (Klunzinger, 1872) & $5-200$ & EI, WP: southwestern to southeastern Australia & \\
\hline A. japonicus Hubbs, 1915 & $85-154$ & EI, WP: southern Japan to northern Australia & \\
\hline A. laterna (Walbaum, 1792) & $45-200$ & $\begin{array}{l}\text { EA, MS: Mediterranean and Black seas; eastern } \\
\text { Atlantic from Norway to Angola }\end{array}$ & \\
\hline A. dalgleishi (von Bonde, 1922) & $50-220$ & $\begin{array}{l}\text { WI, EI, WP: South and East Africa east to Loyalty } \\
\text { Islands }\end{array}$ & \\
\hline A. capensis Boulenger, 1898 & $70-200$ & $\begin{array}{l}\text { EA, WI: Mauritania to South Africa, Saint Helena } \\
\text { and Ascension Is. }\end{array}$ & $\begin{array}{l}\text { Synonym: A. entomorhynchus } \\
\text { Stauch, } 1967\end{array}$ \\
\hline A. arabicus Norman, 1939 & $83-220$ & $\begin{array}{l}\text { RS, WI: southern Red Sea and northwestern Indian } \\
\text { Ocean }\end{array}$ & \\
\hline A. thori Kyle, 1913 & $5-300$ & $\begin{array}{l}\text { EA, MS: Mediterranean and Black seas, and } \\
\text { eastern Atlantic from Ireland to Sierra Leone }\end{array}$ & $\begin{array}{l}\text { Synonym: A. moltonii } \\
\text { Torchio, } 1961\end{array}$ \\
\hline A. elongatus Weber, 1913 & $100-224$ & $\begin{array}{l}\text { EI, WP: Taiwan to Indonesia and northwestern } \\
\text { Australia }\end{array}$ & \\
\hline $\begin{array}{l}\text { A. kotthausi Klausewitz and Schneider, } \\
1986\end{array}$ & $138-225$ & WI: northwestern Indian Ocean & $\begin{array}{l}\text { Synonym: A. profundus } \\
\text { Kotthaus, 1977, preoccupied } \\
\text { by A. profundus Weber, } 1913\end{array}$ \\
\hline A. imperialis (Rafinesque, 1810) & $15-350$ & $\begin{array}{l}\text { EA, MS: western Mediterranean and eastern } \\
\text { Atlantic from Scotland to Namibia }\end{array}$ & $\begin{array}{l}\text { Synonym: A. blachei, Stauch } \\
1965\end{array}$ \\
\hline $\begin{array}{l}\text { A. sayaensis Amaoka and Imamura, } \\
1990\end{array}$ & $125-254$ & WI: Saya de Malha Bank and Madagascar & \\
\hline A. polyspilus (Günther, 1880) & $4-390$ & EI, WP: India east to New Caledonia, north to Japan & \\
\hline A. multirastris Parin, 1983 & $160-265$ & EP: Nazca Ridge & \\
\hline A. oxyrhynchus Amaoka, 1969 & 215 & WP: Japan; Chesterfield Islands & \\
\hline A. brunneus (Fowler, 1934) & $187-292$ & WP: Philippines to Vanuatu & \\
\hline $\begin{array}{l}\text { A. septemventralis Amaoka and } \\
\text { Mihara, } 2000\end{array}$ & $240-250$ & WP: New Caledonia & \\
\hline A. nigrifrons Amaoka and Mihara, 2000 & 300 & WP: Chesterfield Islands & \\
\hline A. debilis (Gilbert, 1905) & $150-440$ & WP: Indonesia east to Hawaiian and Line Islands & \\
\hline A. scapha (Forster, 1801) & 4-737 & WP: New Zealand & $\begin{array}{l}\text { Junior synonym: } \\
\text { Pseudorhombus boops Hector, } \\
1875\end{array}$ \\
\hline $\begin{array}{l}\text { A. marisrubri Klausewitz and } \\
\text { Schneider, } 1986\end{array}$ & $363-383$ & RS: central Red Sea & \\
\hline A. rueppelii (Cocco, 1844) & $85-897$ & $\begin{array}{l}\text { EA, MS: Mediterranean Sea and eastern Atlantic } \\
\text { from Gibraltar to Western Sahara }\end{array}$ & \\
\hline A. armstrongi Scott, 1975 & $?$ & EI: Tasmania, Australia & \\
\hline A. tapeinosoma (Bleeker, 1865) & $?$ & EI, WP: Sumatra (Indonesia), China & \\
\hline
\end{tabular}

Description. Counts and measurements of the holotype and paratypes listed in Table 2 are part of this description.

Body oval, laterally strongly compressed, eyes on the left side of body (the "ocular side"), right side of body without eyes (the "blind side"). Body depth 2.4 (2.3-2.5) in SL [42.3\% (40.4\%-44.2\%) of SL]. Head length $4.0(4.1-4.3)$ in SL $[24.7 \%(23.2 \%-24.2 \%)$ of SL]. Snout slightly pointed, completely scaled. Anterior teeth in upper jaw not enlarged, prevomer not enlarged, weakly projecting into mouth cavity. Both nostrils situated anterior to the eyes. Upper orbit diameter 3.4 (3.0-3.3) in head length [7.3\% (7.2\%-
$7.8 \%$ ) of SL]; lower orbit diameter 3.4 (3.0-3.4) in head length $[7.2 \%(7.1 \%-8.0 \%)$ of SL]. Interorbital a narrow bony ridge, in the middle without scales, interorbital distance 19.9 (16.5-26.2) in head length [1.2\% $(0.9 \%-1.5 \%)$ of SL]. Scales on orbital and blind sides cycloid. Lateral line arched over pectoral fin (arch formed by anterior 11-12 scales); lateral-line scales 54 (52-53). Caudal peduncle depth 8.4 (8.4-8.5) in SL [11.9\% (11.7\%-12.0\%) of SL]. Precaudal vertebrae 10 (10), caudal vertebrae 30 (30).

Dorsal fin with 83 (78-84) soft rays, the second to sixth rays elongate and filamentous. Anal fin with 66 (61-66) soft rays. Caudal fin distally rounded, caudal-fin 

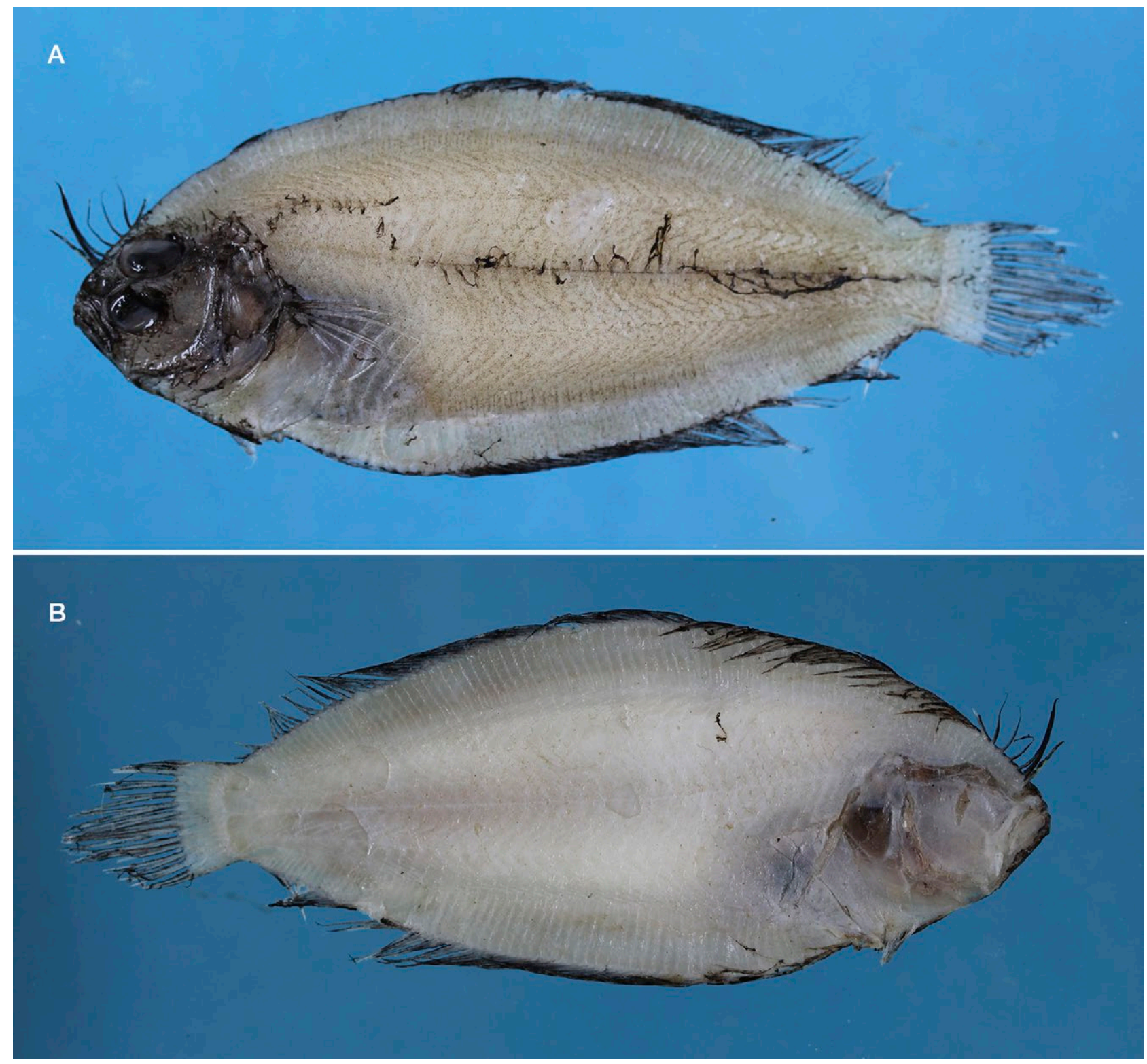

Fig. 1. - Arnoglossus nigrofilamentosus n. sp., HUJ 20663, holotype, $96.6 \mathrm{~mm}$ SL, Jaffa, Israel. A, ocular side; B, blind side. Photographs by D. Golani.

rays iii,11,iii (iii,11,iii). Length of longest caudal-fin ray $5.0(5.0-5.4)$ in SL $[19.9 \%(18.6 \%-20.0 \%)$ of SL]. Pectoral fin with 13 (12-13) soft rays on ocular side, with 9 (7-9) rays on blind side. Pectoral-fin length 7.4 (6.0$6.8)$ in SL $[13.5 \%(14.7 \%-16.7 \%)$ of SL] on ocular side, $10.7(9.5-10.5)$ in SL $[9.3 \%(9.5 \%-10.5 \%)$ of SL] on blind side. Pelvic-fin length 7.7 (6.7-11.6) in SL [12.9\% $(8.6 \%-15.0 \%)$ of SL] on ocular side, $15.8(12.2-15.5)$ in SL $[6.3 \%(6.6 \%-8.2 \%)$ of SL] on blind side.

Colour of fresh specimen (Fig. 1). Head and body pale yellowish (may have been dark before the epidermis was abrased), head black, peritoneum dark. Dorsal-fin filaments, rays and membranes black; anal fin black, membranes distal three-fourths of caudal fin black. Pectoral fins yellowish, pelvic fin on ocular side blackish, on blind side pale.
Etymology. In the scientific name filamentosus means filamentous, and niger means black; the name refers to the black filamentous anterior dorsal-fin rays.

Distribution. So far, this new species is only known from off Jaffa, on the eastern Mediterranean coast of Israel (Fig. 3). However, as this species has not been found in the Mediterranean Sea before, and as it has close similarities with Indo-Pacific species, it is probable that it originally came from the Gulf of Suez (Red $\mathrm{Sea}$, and is another case of Lessepsian migration.

Comparison. Arnoglossus nigrofilamentosus n. sp. is compared with other similar species bearing elongate, filamentous rays on the anterior dorsal fin in Table 3; the filament patterns are compared in Figure 4. It is distinguished from the other species of the genus by the presence of filamentous dorsal-fin rays. 


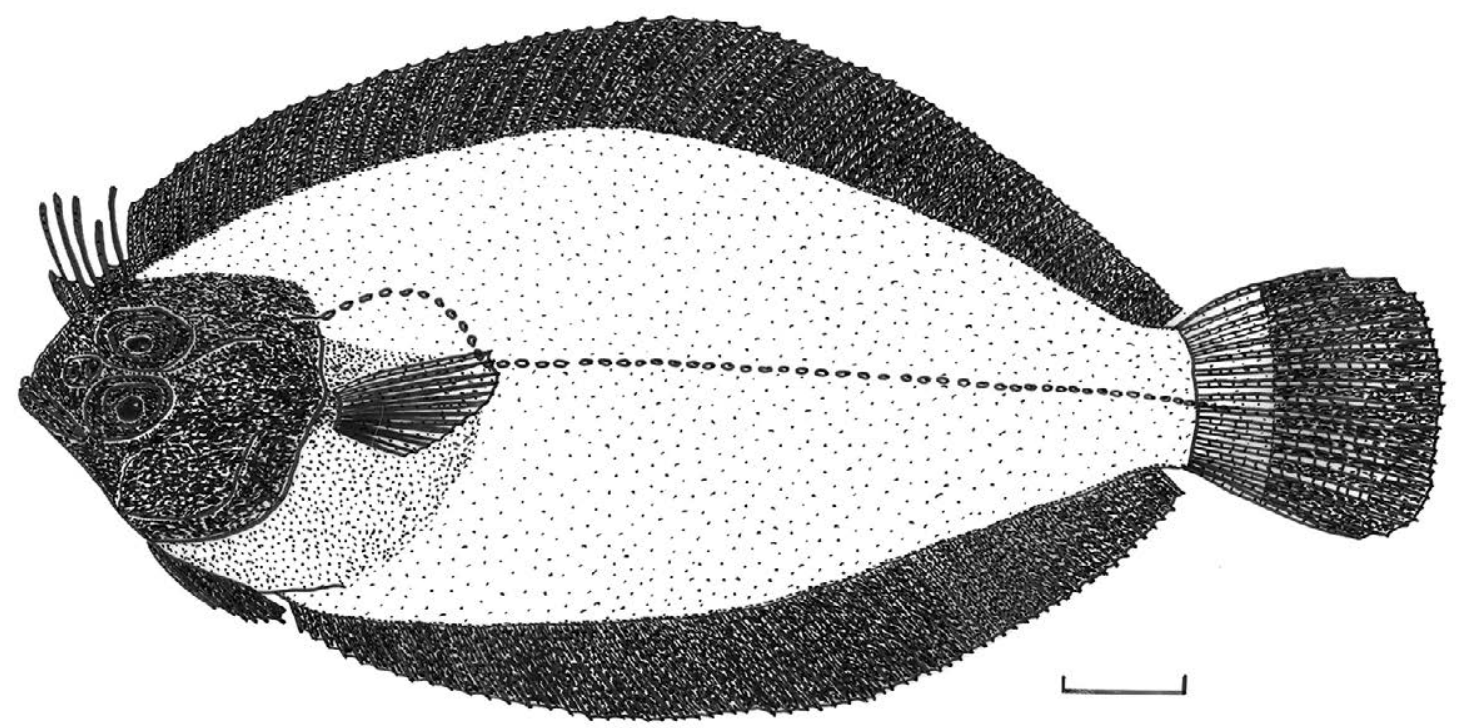

Fig. 2. - Arnoglossus nigrofilamentosus n. sp., HUJ 20663, holotype, 96.6 mm SL, Jaffa, Israel. Sketch of ocular side of preserved specimen.

Table 2. - Counts and measurements [mm] of Arnoglossus nigrofilamentosus n. sp., HUJ 20663 (holotype, 96.6 mm SL), and HUJ 20664 (3 paratypes, 84.4-90.6 mm SL), Israel, Jaffa, eastern Mediterranean Sea.

\begin{tabular}{|c|c|c|c|c|}
\hline & Holotype, HUJ 20663 & Spec. 1 & $\begin{array}{c}\text { pes, HUJ } \\
\text { Spec. } 2\end{array}$ & Spec. 3 \\
\hline Dorsal-fin rays & 83 & 84 & 80 & 78 \\
\hline Anal-fin rays & 66 & 65 & 61 & 66 \\
\hline Pectoral-fin rays (ocular side) & 13 & 13 & 12 & 13 \\
\hline Pectoral-fin rays (blind side) & 9 & 8 & 9 & 7 \\
\hline Caudal-fin rays & iii, 11 ,iii & iii,11,iii & iii,11,iii & iii, 11 ,iii \\
\hline Lateral-line scales & 54 & 52 & 53 & 53 \\
\hline Gill rakers on first arch (ocular side) & $0+5$ & $0+5$ & $0+5$ & $0+4$ \\
\hline Vertebrae & $10+30$ & $10+30$ & $10+30$ & $10+30$ \\
\hline SL & 96.6 & 90.6 & 88.7 & 84.4 \\
\hline Head length (ocular side) & 23.9 & 21.0 & 21.5 & 20.1 \\
\hline Body depth & 40.9 & 39.7 & 39.2 & 34.1 \\
\hline Upper orbit diameter & 7.1 & 7.1 & 6.9 & 6.1 \\
\hline Lower orbit diameter & 7.0 & 6.9 & 6.8 & 6.0 \\
\hline Interorbital width & 1.2 & 0.8 & 1.3 & 1.0 \\
\hline Upper jaw length & 7.2 & 7.4 & 7.0 & 6.3 \\
\hline Lower jaw length (ocular side) & 6.5 & 5.5 & 5.8 & 4.8 \\
\hline Lower jaw length (blind side) & 8.3 & 6.9 & 7.8 & 7.9 \\
\hline Caudal peduncle depth & 11.5 & 10.7 & 10.6 & 9.9 \\
\hline Length of longest dorsal-fin ray & 10.0 & 11.4 & 9.3 & 10.3 \\
\hline Length of longest anal-fin ray & 9.9 & 10.7 & 7.9 & 8.4 \\
\hline Pectoral-fin length (ocular side) & 13.0 & 13.3 & 14.8 & 12.6 \\
\hline Pectoral-fin length (blind side) & 9.0 & 9.5 & $4.9+$ & 8.4 \\
\hline Pelvic-fin length (ocular side) & 12.5 & 7.8 & 13.3 & 6.1 \\
\hline Pelvic-fin length (blind side) & 6.1 & 7.2 & 7.3 & 5.6 \\
\hline Length of pelvic-fin base (ocular side) & 6.3 & 5.5 & 6.0 & 5.1 \\
\hline Length of pelvic-fin base (blind side) & 1.6 & 1.9 & 1.4 & 1.5 \\
\hline Length of longest caudal-fin ray & 19.2 & $14.3+$ & 17.7 & 15.7 \\
\hline
\end{tabular}

Among the Mediterranean species of Arnoglossus, this new species is very distinctive in having a low number of $0+4-5$ gill rakers (versus $0+7-13$ in the other species), the 2nd to 6th anterior dorsal-fin rays elongate and bearing black filaments (versus anterior dorsal-fin rays either not elongate and filamentous, or a single ray elongate and bearing a black filament in male $A$. thori, or else several anterior rays with long white filaments in A. imperialis), and the dorsal and anal fins black (versus pale, sometimes with spots or only the anterior rays black). For easy distinguishing of co-occurring species like A. grohmanni, A. laterna,
A. rueppellii and A. thori, a key to the species of Arnoglossus of the Mediterranean and eastern Atlantic is provided below.

Compared with the Red Sea and western Indian Ocean species of the genus, the new species is also unique in having a low number of 78-84 dorsal-fin rays (versus 91-110), 61-66 anal-fin rays (versus 70-86) and 0+4-5 gill rakers (versus 0+6-13); it also differs from other species in having the anterior teeth of the upper jaws not enlarged (versus enlarged in A. dalgleishi, A. kotthausi and A. sayaensis), and the prevomer small, barely projecting into the mouth cavity (versus large, 


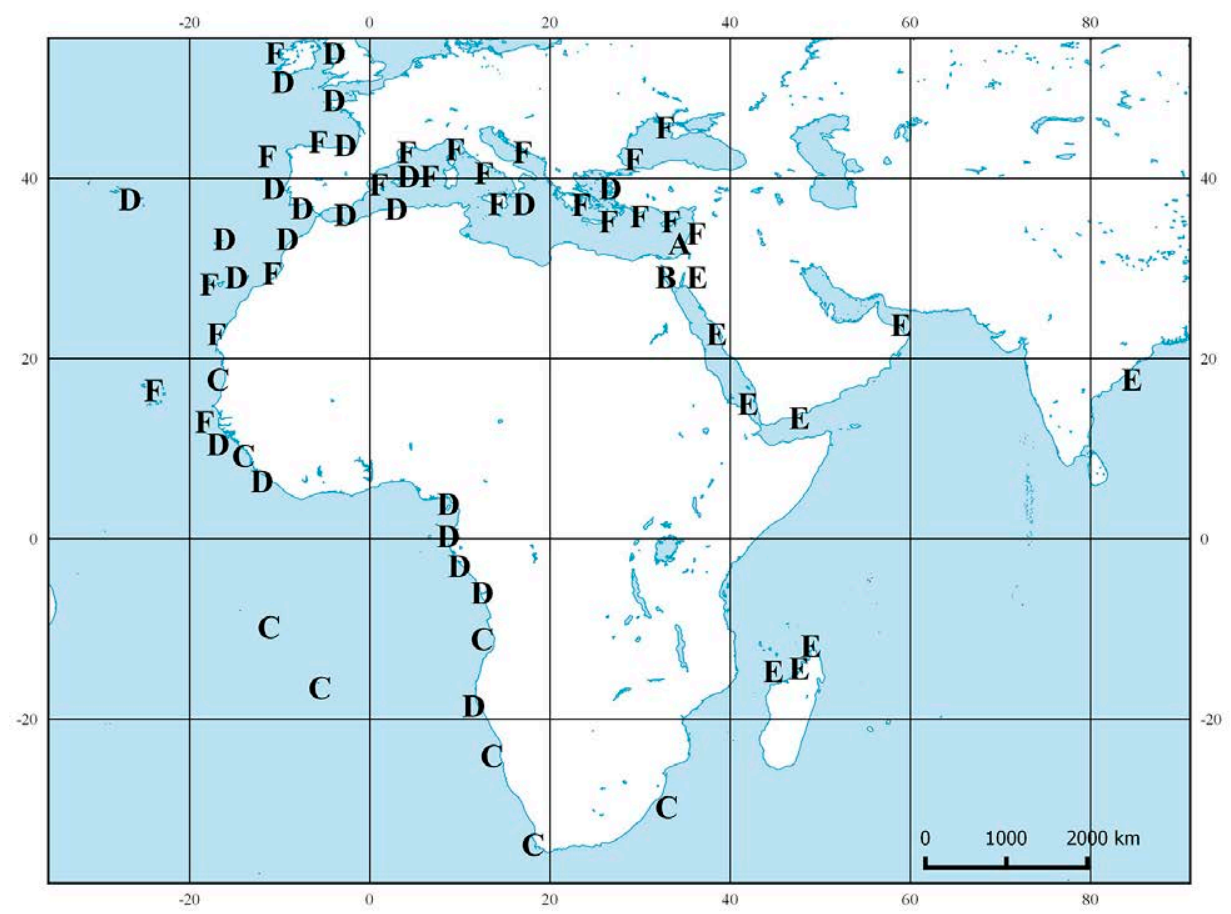

Fig. 3. - Geographical distribution of species of Arnoglossus with several elongate and filamentous rays in anterior dorsal fin, eastern Atlantic, Mediterranean and western Indian Ocean. A, A. nigrofilamentosus $\mathrm{n}$. sp., type locality. B, A. nigrofilamentosus $\mathrm{n}$. sp., presumed original distribution. C, A. capensis. D, A. imperialis. E, A. macrolophus. F, A. thori.

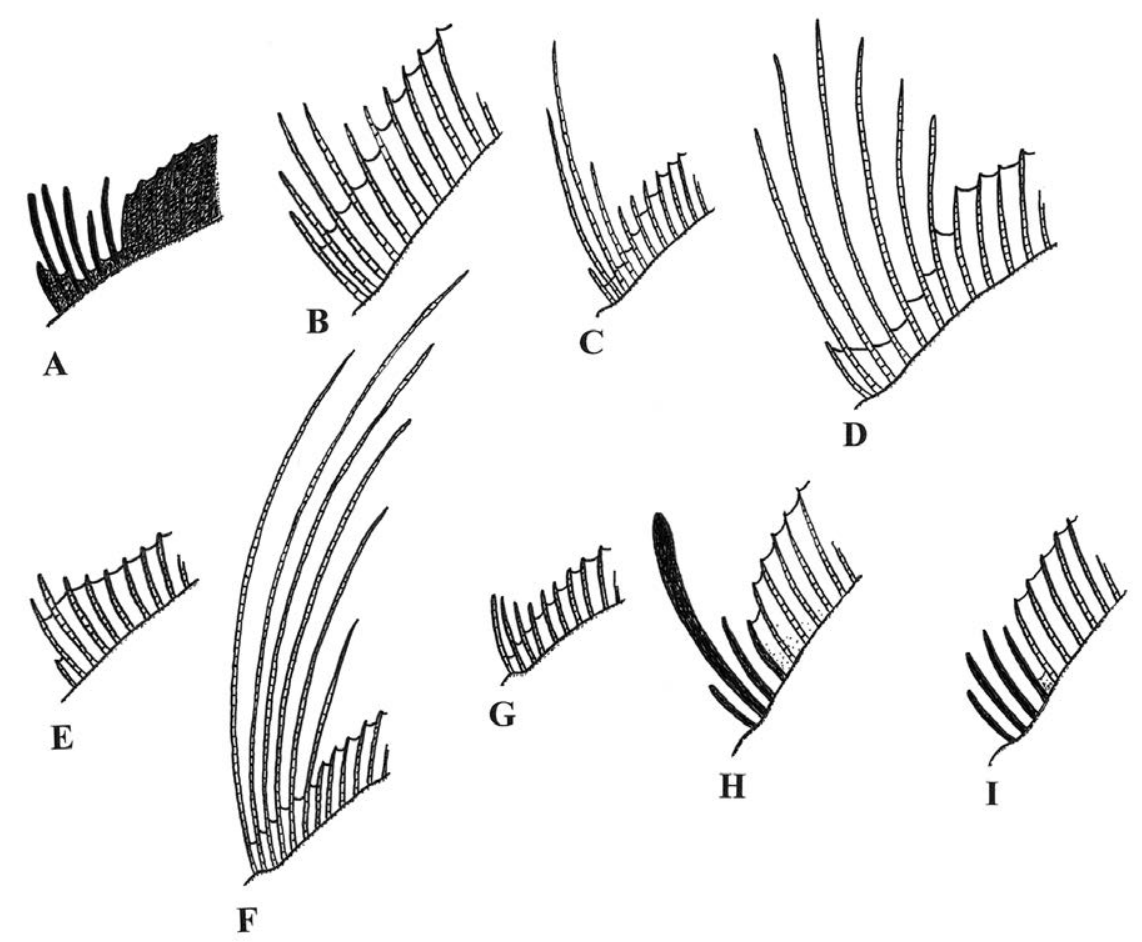

Fig. 4. - Dorsal-fin filaments and anterior dorsal-fin coloration of species of Arnoglossus with several elongate and filamentous rays on anterior dorsal fin, eastern Atlantic, Mediterranean and Indian Ocean. A, A. nigrofilamentosus n. sp. B, A. capensis. C, A. elongatus. D, A. imperialis (male). E, A. imperialis (female). F, A. macrolophus (male). G, A. macrolophus (female). H, A. thori (male). I, A. thori (female).

strongly projecting into the mouth cavity in $A$. macrolophus). It is distinguished from $A$. marisrubri by the presence of filamentous rays on the dorsal fin (versus no filamentous rays on the dorsal fin), dorsal-fin rays 78 to
84 (versus 95 to 97), anal-fin rays 61 to 66 (versus 74 to 77), and gill rakers $0+4-5$ (versus $0+11-13$ ). A key to distinguishing the species of Arnoglossus of the Red Sea and the western Indian Ocean is provided below. 
$\Xi$

言

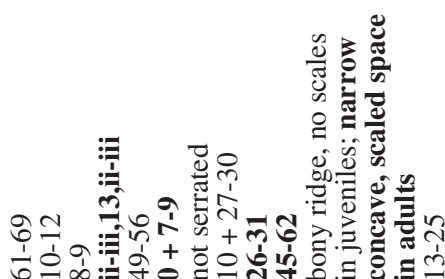

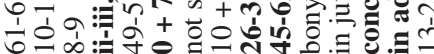

(n)

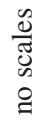

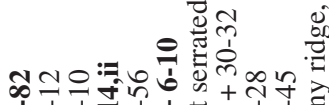

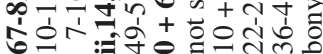

خ్ర

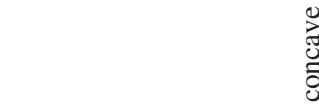

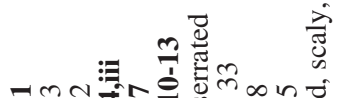

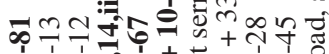

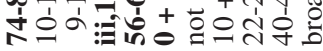

$\frac{0}{\tilde{J}}$

0
0
0
0
0

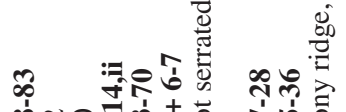

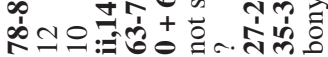

$\frac{\tilde{s}}{\tilde{m}}$

き

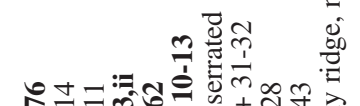

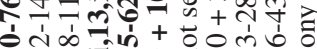

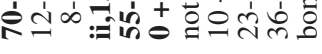

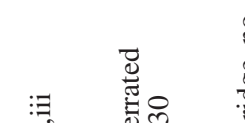

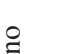

$$
\text { กิ }
$$

正

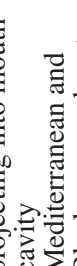

콩 웅

ซै $\frac{\pi}{0}$

正

sं

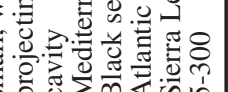

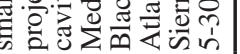

要

递要

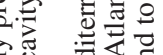

年

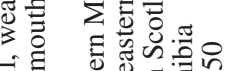

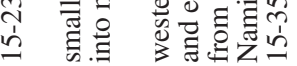

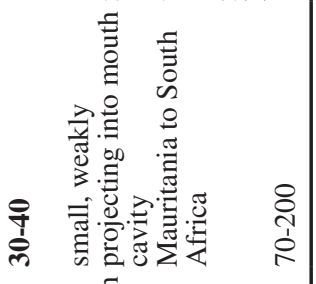

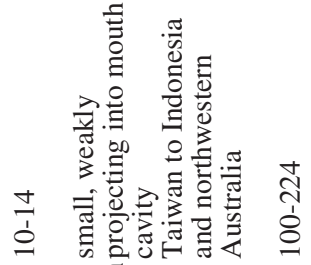

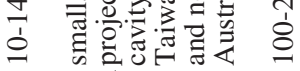

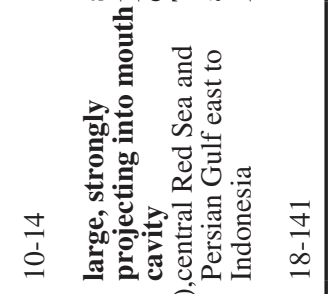

○

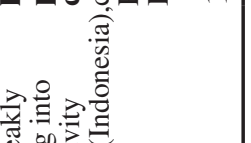

3.00

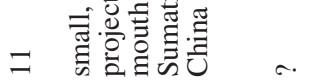

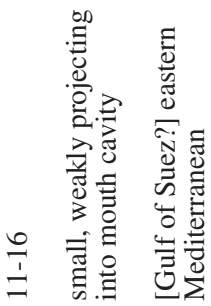

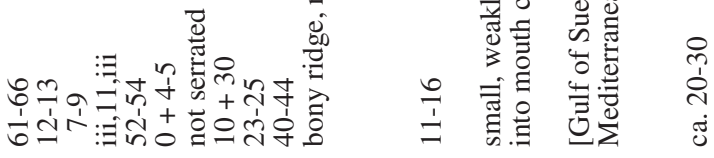

웡요

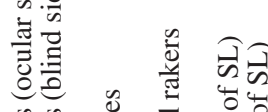

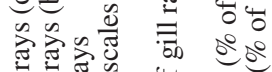

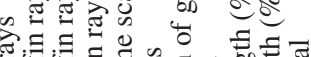

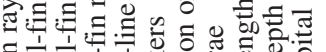

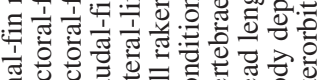

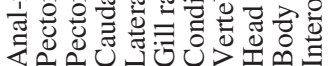

\section{DISCUSSION}

The specimens described herein agree well with the generic characters of the genus Arnoglossus as defined by Norman (1934) and Amaoka (1969), including the pelvic fin on the ocular side beginning at the tip of the isthmus, the eyes separated by a bony ridge, the head large, more than $22 \%$ of SL $(23.2 \%$ $24.7 \%$ ), the scales on the ocular side cycloid, and the mouth large, maxillary longer than eye diameter. However, they do not agree with any of the known species of Arnoglossus from the Mediterranean/eastern Atlantic, from the Red Sea/ Indian Ocean, or from any other region.

This finding of a new species of Arnoglossus from off the Mediterranean coast of Israel is quite surprising, as there has been an extensive fishing effort in this habitat for many decades. However, the species was previously not detected and there is no material available in the regional ichthyological collections, so it is unlikely that it was just missed. The close similarity of this new species to other species occurring in the central Red Sea and the northwestern Indian Ocean (A. arabicus, A. macrolophus and $A$. marisrubri), and the obvious previous absence from the southeastern Mediterranean, makes it likely that this represents another case of Lessepsian migration, and that A. nigrofilamentosus n. sp. originates from the Gulf of Suez. Unfortunately, the Gulf of Suez ichthyofauna is incompletely known and under-represented in ichthyological collections, which makes it more likely that the new species was previously missed in that region.

The opening of the Suez Canal in 1869 connected the Red Sea with the Mediterranean, resulting in an almost unidirectional migration of Red Sea organisms into the Mediterranean ("Lessepsian migration") (Golani et al. 2002). A complete list of species to 2010 was provided by Golani (2010). Fricke et al. (2015) provided a list of additional Lessepsian migrant species, which resulted in a total of 97 migrant species confirmed in the Mediterranean. Galil et al. (2015) discussed the recent widening of the Suez Canal and the probability of increased Lessepsian migration. Russell et al. (2015) discovered that the species previously misidentified as Saurida undosquamis (non Richardson, 1848) or S. macrolepis (non Tanaka, 1917) from the northern Red Sea and the Mediter- 
ranean belonged to a distinct, undescribed species that they named Saurida lessepsianus Russell, Golani and Tikochinski, 2015. Subsequently, the following confirmed species were recorded: Cryptocentrus caeruleopunctatus (Rüppell, 1830), family Gobiidae (Rothman and Goren 2015); Mobula japanica (Müller and Henle, 1841), family Mobulidae (Capapé et al. 2015); Encrasicholina gloria Hata and Motomura, 2016, family Engraulidae (Hata and Motomura 2016); Epinephelus areolatus (Forsskål, 1775), family Serranidae (Rothman et al. 2016); Diplogrammus randalli Fricke, 1983, family Callionymidae (Seyhan et al. 2017). Lessepsian migrant fish species therefore currently stand at a total of 102 species.

\section{Key to the species of Arnoglossus of the Mediterranean Sea and the eastern Atlantic}

Remark: This key is updated, based on Munroe (2016) and Nielsen in Whitehead et al. (1986).

1. Dorsal-fin rays 110-118; anal-fin rays 86-94 A. rueppellii

- Dorsal-fin rays less than 110; anal-fin rays less than 85

2. Gill rakers $0+4-5$; dorsal and anal fins plain black A. nigrofilamentosus $\mathrm{n}$. sp.

- Gill rakers 0 + 7-13; dorsal and anal fins pale, sometimes with dark spots or only anterior rays black..3

3. Dorsal-fin rays $74-80$; anal-fin rays $51-57$ A. grohmanni

- Dorsal-fin rays 81 or more; anal-fin rays 61 or more.....

4. Dorsal-fin rays 81 to 93 ; anal-fin rays 61 to $74 \ldots . .5$

- Dorsal-fin rays 95 to 106 ; anal-fin rays 74 to $82 \ldots 6$

5. No elongate dorsal-fin rays; no dark markings on ocular-side pectoral fin; no series of dark spots present along base of caudal fin .... A. laterna

- Second dorsal-fin ray of males elongate (more than $60 \%$ of head length) with dark-fringed, broad membrane (1st, 3rd and 4th dorsal-fin rays may also be elongate, but these are only about one-third as long as second ray); ocular-side pelvic fin often with dark spot or blotch on posterior rays; a series of dark spots often present along base of caudal fin....

A. thori

6. Dorsal-fin rays 2 to 5 or 2 to 6 elongate (elongate rays nearly equal to head length in males); eyes separated by a bony ridge; lateral-line scales 49 to 56 ; 6 to 9 gill rakers on lower limb of first gill arch; males with distinct black spot on posterior ocular-side pelvic-fin rays, females with greyish, sometimes indistinct, spot on posterior ocular-side pelvic-fin rays. A. imperialis

- Anterior 3 or 4 dorsal-fin rays of males noticeably prolonged and of nearly equal length; eyes separated by a concave scaly space; lateral-line scales
56 to $66 ; 10$ to 13 gill rakers on lower limb of first gill arch; no dark markings on ocular-side pelvicfin rays A. capensis

\section{Key to the species of Arnoglossus of the Red Sea and the western Indian Ocean}

Remark: This key is updated, based on Klausewitz and Schneider (1986), Amaoka and Imamura (1990) and Arai and Amaoka (1996); though this species has not yet been recorded from the region, it also includes A. nigrofilamentosus $\mathrm{n}$. sp., as this is of putative Red Sea origin.

1. Anterior teeth of upper jaw significantly enlarged compared with those on the sides....

- Anterior teeth of upper jaw scarcely enlarged or not enlarged

2. Dorsal-fin rays 102 to 110 ; lateral-line scales 72 to 76 A. savayensis

- Dorsal-fin rays 91 to 99; lateral-line scales 56 to 70

3. Dorsal-fin rays 95 to 99; lateral-line scales 70; gill rakers $0+7$................................... A. dalgleishi

- Dorsal-fin rays 91 to 96; lateral-line scales 56-60; gill rakers $0+11-13$ A. kotthausi

4. Dorsal-fin rays 78 to 84 ; anal-fin rays 61 to 66 ; gill rakers $0+4-5$............. A. nigrofilamentosus n. sp.

- Dorsal-fin rays 91 to 102; anal-fin rays 70 to 78; gill rakers $0+10-13$

5. Prevomer large, strongly projecting into mouth cavity; anterior dorsal-fin rays elongate and filamentous in the male; head length $23 \%-28 \%$ of SL

A. macrolophus

- Prevomer small, not much projecting into mouth cavity; anterior dorsal-fin rays not elongate or barely elongate in the male; head length $27 \%-31 \%$ of SL

6. Body depth $36 \%-40 \%$ of SL; dorsal-fin rays 95 to 97; anterior dorsal-fin rays with short filaments ..... A. arabicus

- Body depth 32\%-38\% of SL; dorsal-fin rays 96 to 102; anterior dorsal-fin rays without filaments ....... A. marisrubri

\section{ACKNOWLEDGEMENTS}

We would like to thank N. Gluzman, Captain of the trawler F/V Bilu, for allowing us to examine the catch on his vessel.

\section{REFERENCES}

Amaoka K. 1969. Studies on the sinistral flounders found in the waters around Japan: taxonomy, anatomy and phylogeny. J. Shimonoseki Univ. Fish. 18: 65-340.

Amaoka K., Imamura H. 1990. Two new and one rare species of bothid flounders from Saya de Malha Bank, Indian Ocean (Tel- 
eostei: Pleuronectiformes). Copeia 1990: 1011-1019. https://doi.org/10.2307/1446484

Arai M., Amaoka K. 1996. Arnoglossus macrolophus Alcock (Pleuronectiformes: Bothidae); a valid species distinct from $A$. tapeinosomus (Bleeker). Ichthyol. Res. 43: 359-365. https://doi.org/10.1007/BF02347635

Capapé C., Rafrafi-Nouira S., El Kamel-Moutalibi O., et al. 2015. First Mediterranean records of spine tail devil ray, Mobula japanica (Elasmobranchii: Rajiformes: Mobulidae). Acta Ichthyol. Piscat. 45: 211-215. https://doi.org/10.3750/AIP2015.45.2.13

Dor N. 1970. Contributions to the knowledge of the Red Sea. No. 44. Nouveaux poissons pour la faune de la mer Rouge. Bull. Sea Fish. Res. Stn. Haifa 54: 7-28.

Eschmeyer W.N., Fong J.D. 2017. Species by family/subfamily in the Catalog of fishes, electronic version (31 August 2017). Internet publication, California Academy of Sciences, San Francisco.

http://researcharchive.calacademy.org/research/ichthyology/ catalog/SpeciesByFamily.asp

Eschmeyer W.N., Fricke R., Laan R. van der (eds). 2017. Catalog of fishes, electronic version (31 August 2017). Internet publication, California Academy of Sciences, San Francisco. http://researcharchive.calacademy.org/research/ichthyology/ catalog/fishcatmain.asp

Fricke R. 1983. A method of counting caudal fin rays of actinopterygian fishes. Braunschw. Natkdl. Schr. 1: 729-733.

Fricke R. 2017. References in the Catalog of fishes, electronic version (31 August 2017). Internet publication, California Academy of Sciences, San Francisco.

http://research.calacademy.org/research/Ichthyology/Catalog/ fishcatmain.asp

Fricke R., Golani D., Appelbaum-Golani B. 2015. First record of the Indian anchovy Stolephorus indicus (van Hasselt, 1823) (Clupeiformes: Engraulidae) in the Mediterranean Sea. BioInvasions Rec. 4: 293-297. https://doi.org/10.3391/bir.2015.4.4.11

Galil B., Boero F., Fraschetti S., et al. 2015. The enlargement of the Suez Canal and introduction of non-indigenous species to the Mediterranean Sea. Limnol. Oceanogr. Bull. 24: 43-45. https://doi.org/10.1002/lob.10036

Golani D. 2010. Colonization of the Mediterranean by Red Sea fishes via the Suez Canal-Lessepsian Migration. In: Golani D., Appelbaum-Golani B. (eds), Fish invasions of the Mediterranean Sea - change and renewal. Sofia: Pensoft, pp 145-188.

Golani D., Orsi-Relini L., Massutí E., et al. 2002. CIESM atlas of exotic species in the Mediterranean. In: Briand F. (ed.), Fishes, vol. 1. CIESM Publ., Monaco, 256 pp.

Hata H., Motomura H. 2016. Two new species of the genus Encrasicholina (Clupeiformes: Engraulidae): E. intermedia from the western Indian Ocean and E. gloria from the Persian Gulf, Red Sea and Mediterranean. Raffles Bull Zool. 64: 79-88.

Hensley D.A., Amaoka K. 2001. Family Bothidae. In: Carpenter K.E., Niem V.H. (eds). Species identification guide for fishery purposes. The living marine resources of the western central Pacific. Bony fishes part 4 (Labridae to Latimeriidae), estuarine crocodiles, sea turtles, sea snakes and marine mammals. Vol. 6. FAO, Rome, pp. 3799-3841.

Hubbs C.L., Lagler K.F. 1947. Fishes of the Great Lakes Region. Bull. Cranbrook Inst. Sci., Bloomfield Hills, Michigan, 26: vi+186 pp.

Klausewitz W., Schneider M. 1986. Tiefenwasser- und Tiefseefische aus dem Roten Meer. XII. Arnoglossus marisrubri n. sp. aus dem Mesobenthos des zentralen Roten Meeres und A. kotthausi nom. nov. vom Epibenthos des nordwestlichen Indischen Ozeans. (Pisces: Pleuronectiformes: Bothidae: Bothinae). Senckenb. Marit. 18: 217-227, pl. 1.

Munroe T.A. 2016. Bothidae. In: Carpenter K.E., De Angelis N. (eds). The living marine resources of the Eastern Central Atlantic. Vol. 4. Bony fishes part 2 (Perciformes to Tetradontiformes) and Sea turtles. FAO Species Identification Guide for Fishery Purposes. FAO, Rome. pp. 2973-2993

Nelson J.S., Grande T.L., Wilson M.V.H. 2016. Fishes of the world. Fifth edition. John Wiley and Sons, Hoboken, NJ, USA, xli + 707 pp. https://doi.org/10.1002/9781119174844

Norman J.R. 1934. A systematic monograph of the flatfishes (Heterosomata). Vol. 1. Psettodidae, Bothidae, Pleuronectidae. British Museum (Natural History): viii $+459 \mathrm{pp}$

Rothman S.B.S., Goren M. 2015. First record of the Red Sea shrimp-goby Cryptocentrus caeruleopunctatus in the Mediterranean Sea. Mar. Biodiversity Rec. 8 (e157): 1-2. https://doi.org/10.1017/S1755267215001323

Rothman S.B.S., Stern N., Goren M. 2016. First record of the Indo-Pacific areolate grouper Epinephelus areolatus (Forsskål, 1775) (Perciformes: Epinephelidae) in the Mediterranean Sea. Zootaxa 4067: 479-483. https://doi.org/10.11646/zootaxa.4067.4.7

Russell B.C., Golani D., Tikochinski Y. 2015. Saurida lessepsianus a new species of lizardfish (Pisces: Synodontidae) from the Red Sea and Mediterranean Sea, with a key to Saurida species in the Red Sea. Zootaxa 3956: 559-568 https://doi.org/10.11646/zootaxa.3956.4.7

Seyhan D., Irmak E., Fricke R. 2017. Diplogrammus randalli (Pisces: Callionymidae), a new Lessepsian migrant recorded from the Mediterranean Sea. Mediterranean Mar. Sci. 18: 1-3. https://doi.org/10.12681/mms.1948

Whitehead P.J.P., Bauchot M.-L., Hureau J.-C., et al. 1986. Fishes of the North-eastern Atlantic and the Mediterranean. Vol. 3. UNESCO, Paris: 1015-1473. 